Vol. 1 (Juni 2019): 1 - 12

\title{
PEMBERDAYAAN KAMPOENG RABBIT'S UNTUK MEWUJUDKAN DAERAH TENAYAN RAYA MENJADI OBJEK WISATA
}

\author{
Sri Nanda ${ }^{1}$, Widya Rahma Ananda ${ }^{2}$, Opi Savira ${ }^{3}$, Zul Hazmi Alfurqani ${ }^{4}$, Rahmat Hidayat ${ }^{5}$, M. S \\ Dony Saputra ${ }^{6}$, Martina Lucas ${ }^{7}$, Alfikri Habibullah ${ }^{8}$, Mailia Ulva ${ }^{9}$, Tika Rahayu ${ }^{10}$, Ranti Darwin ${ }^{11}$ \\ $1,2,3,4,5,6,7,8,11$ Prodi Ekonomi Pembangunan, Fakultas Ekonomi dan Bisnis \\ 9,10Prodi Biologi, Fakultas MIPA Dan Kesehatan
}

Submited: 2019.01.23 Reviewed: 2019.01.28 Accepted:2019.06.30

https://doi.org/10.22202/rangkiang.2019.v1.i1.3731

*E-mail:

Srinandawahyuni6@gmail.com, Widyaananda4899@gmail.com, Ophie.syavirra@gmail.com, Hazmi binzalik@gmail.com, Rahmathidayat011zz@gmail.com, Donisahal08@gmail.com,martinalucass180 3@gmail.com, Alfikrihabibullah16@gmail.com, meiliaulfa21@gmail.com, tikar8128@gmail.com, aㅡ nti.darwin@umri.ac.id

\begin{abstract}
Kampoeng Rabbit's is one of the new tourist attractions established in the city of Pekanbaru about 2 years ago precisely on February 2, 2017 which has a land area of $1190 \mathrm{M} 2$ and is located on Jalan Kenanga, Tenayan Raya, this place is a tourist magnet in the Pekanbaru area, especially the Tenayan Raya area. The objectives of this program are: 1) Designing Kampoeng Rabbit's management to be a family-friendly tourist destination. 2) Building a plan in developing Kampoeng Rabbit's in order to become a tourism place that has prospects going forward. Implementation methods of this activity include initial survey activities, problem identification, needs analysis, determination of target audiences, program formulation, formulation and measurement of program success indicators, program implementation, target audience development strategies, partnership and partnership, monitoring and evaluation, results workshop with stakeholders, reporting, and updating post-program target data per 4 months. The results of the activities for the time being are: 1) The people of the Region of Tenayan Raya, especially on Jalan Kenanga, Kelurahan Mentangor Kec. Tenayan Raya can directly feel the impact of this Kampoeng Rabbit's tour. 2) This tourist spot is an educational tourist spot that provides a family-friendly atmosphere that is suitable for extended family trips. 3) Increase the income of Kampoeng Rabbit's manager. 4) Making Kampoeng Rabbit's attraction can be known and known by many people, especially outside the Pekanbaru area. 5) With the cooperation of the owner of the tourist attraction and local community leaders such as the Head of RT and RW Chairman can develop Kampoeng Rabbit's empowerment program to make the Tenayan Raya area a family-friendly tourist attraction.
\end{abstract}

Keywords: Kampoeng Rabbit's, tourist attraction, Tenayan Raya, PHBD

\section{ABSTRAK}

Kampoeng Rabbit's adalah salah satu objek wisata yang baru berdiri di kota Pekanbaru sekitar 2 tahun yang lalu tepatnya pada tanggal 2 Februari 2017 yang berluaskan lahan sebesar $1190 \mathrm{M}^{2}$ dan berlokasi di Jalan Kenanga, Tenayan Raya tempat ini menjadi magnet wisata di daerah Pekanbaru terutama daerah Tenayan Raya. Tujuan dari program ini adalah : 1) Merancang pengelolaan Kampoeng Rabbit's menjadi tempat wisata yang ramah keluarga. 2) Membangun perencanaan dalam mengembangkan Kampoeng Rabbit's agar menjadi tempat pariwisata yang memiliki prospek kedepannya. Metode Pelaksanaan dari kegiatan ini meliputi kegiatan survey awal, identifikasi masalah, analaisis kebutuhan, penetapan khalayak sasaran, penyusunan program, perumusan dan pengukuran indikator keberhasilan program, pelaksanaan program, strategi pembinaan khalayak sasaran, perintidan kemitraan, monitoring dan evaluasi, lokakarya hasil dengan stakeholder, pelaporan, dan pemutkhiran data sasaran pasca program per 4 bulan. Hasil dari kegiatan untuk sementara ini yaitu: 1) Masyarakat Daerah Tenayan Raya terutama di Jalan Kenanga Kelurahan Mentangor Kec. Tenayan Raya dapat merasakan secara langsung dampak adanya wisata Kampoeng Rabbit's ini. 2) 


\section{Rangkiang: لLrnal Pengabdian Pada Masyarakat UPSM STKIP PGRl Sumatera Barat}

Vol. 1 (Juni 2019): 1 - 12

Tempat wisata ini merupakan tempat wisata edukasi yang memberikan suasana ramah keluarga yang cocok untuk keluarga besar berwisata. 3) Meningkatkan pendapatan pengelola Kampoeng Rabbit's ini. 4) Menjadikan objek wisata Kampoeng Rabbit's ini dapat dikenal dan diketahui oleh banyak orang terutama luar daerah Pekanbaru. 5) Dengan adanya kerja sama dari pemilik objek wisata dan tokoh masyarakat setempat seperti Ketua RT dan Ketua RW dapat mengembangkan program pemberdayaan Kampoeng Rabbit's untuk mewujudkan daerah Tenayan Raya menjadi objek wisata yang Ramah keluarga.

Kata kunci : Kampoeng Rabbit's, objek wisata, Tenayan Raya, PHBD

\section{PENDAHULUAN}

Kelinci selalu memiliki pesona tersendiri bagi masyarakat. Kelinci bukan sekedar hewan piaraan yang menghasilkan daging atau hasil pejualannya, melainkan sebagai kesenangan dengan selera tinggi dengan ciri khas yang eksklusif. Ternak ini semula hewan liar yang sulit dijinakkan. Kelinci dijinakkan sejak 2000 tahun silam dengan tujuan keindahan, bahan pangan dan sebagai hewan percobaan. Hampir setiap negara di dunia memiliki ternak kelinci karena kelinci mempunyai daya adaptasi tubuh yang relatif tinggi sehingga mampu hidup di hampir seluruh dunia. Kelinci dikembangkan di daerah dengan populasi penduduk relatif tinggi, Adanya penyebaran kelinci juga menimbulkan sebutan yang berbeda, di Eropa disebut rabbit, Indonesia disebut kelinci, Jawa disebut trewelu dan sebagainya.

Kelinci merupakan satu hewan ternak yang mempunyai banyak manfaat, mulai dari binatang hias, penghasil kompos dari kotoran/fesesnya, tulangnya digunakan sebagai bahan tepung tulang, penghasil daging yang mempunyai gizi tinggi serta rambut dan kulitnya dapat digunakan sebagai bahan kerajinan. Hanya saja karena pemeliharaanya di masyarakat masih bersifat tradisional dan tidak mengikuti kaidah pemeliharaan kelinci secara tepat dan baik, akhirnya banyak peternak kita yang gulung tikar. Kebanyakan peternak hanya memelihara dengan seadanya, dengan tanpa melihat bagaimana sesungguhnya kelinci tersebut. Namun seiring perkembangan zaman peternak kita mulai maju dan perlahan-lahan mulai tahu akan bagaimana beternak kelinci itu sebenarnya.

Kampoeng Rabbit's adalah salah satu objek wisata yang baru berdiri di kota Pekanbaru sekitar 2 tahun yang lalu tepatnya pada tanggal 2 Februari 2017 yang berluaskan lahan sebesar $1190 \mathrm{M}^{2}$ dan berlokasi di Jalan Kenanga, Tenayan Raya tempat ini menjadi magnet wisata di daerah Pekanbaru terutama daerah Tenayan Raya. Wisata yang dihadirkan di tempat ini adalah berbagai kelinci yang berjumlah 300 ekor dan berbagai jenis kelinci seperti kelinci Giant, lion, Nd, Dutch, Rex, Anggora dan lop.

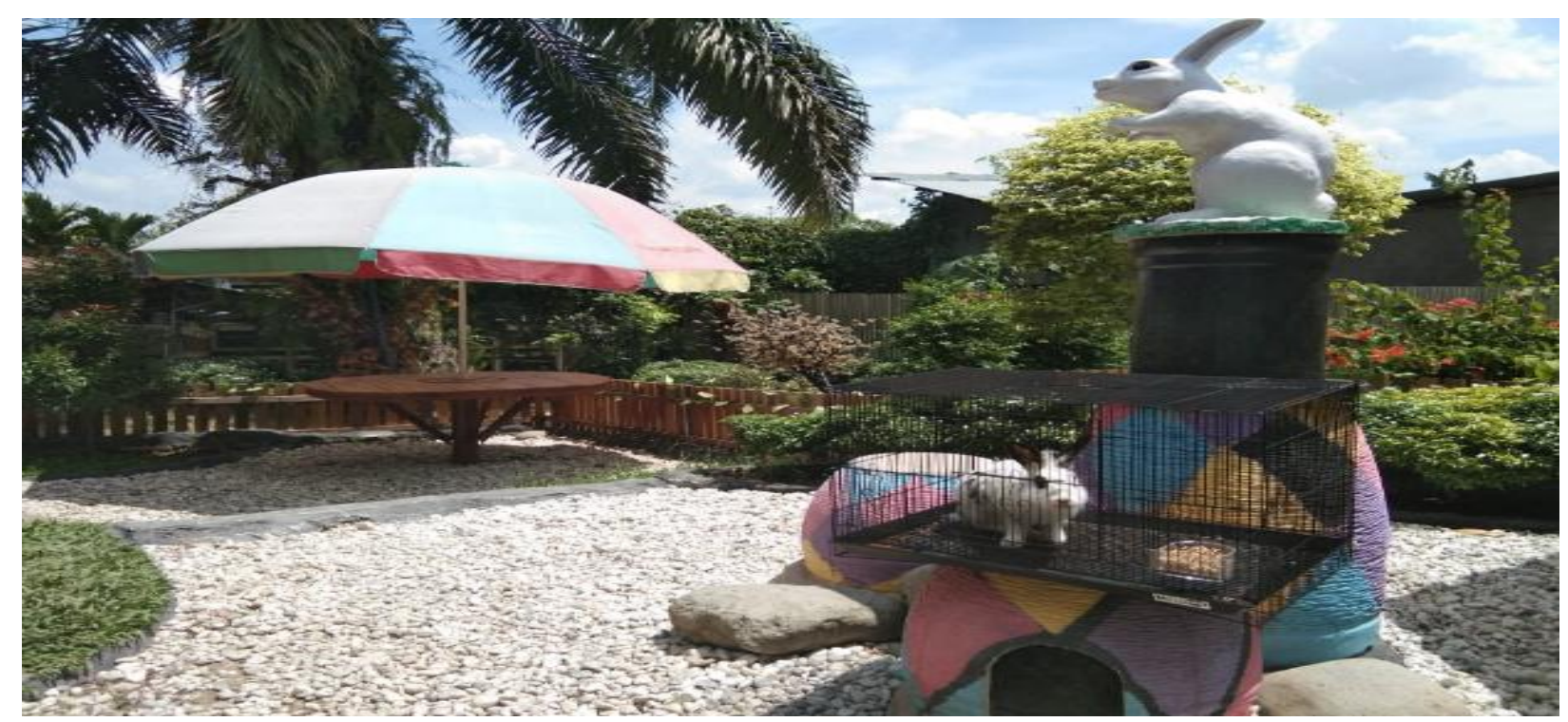

Gambar 1. Taman Kelinci Kampoeng Rabbit's 


\section{Rangkiang: لlurnal Pengabdian Pada Masyarakat UPSM STKIP PGRl Sumatera Barat}

Vol. 1 (Juni 2019): 1 - 12

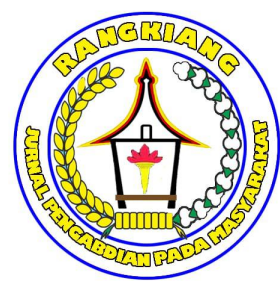

Menurut salah satu sumber yang sekaligus pemilik tempat ini memilih nama "Kampoeng Rabbit's" ini agar masyarakat dapat lebih dekat dengan alam dan lebih menyayangi hewan-hewan sekitar seperti kelinci. Kampoeng Rabbit's ini memang sangat cocok untuk tempat wisata keluarga terlebih lagi untuk anak anak, karena tempat wisata ini memberikan edukasi tentang pemahanan cara memelihara kelinci yang benar,bukan hanya sebagai tempat wisata saja namun kelinci-kelinci di sini banyak mendatangkan manfaat terutama kotorannya karena, bagi pengelola tempat wisata ini kotoran hewan ini bisa mendatangkan pundi-pundi Rupiah sebab kotoran kotoran kelinci ini dijadikan pupuk oleh pemilik sebagai pupuk sawit namun belum ada merknya dan manfaat lainnya kelinci ini dijadikan sebagai sate yang langsung dapat dinikmati oleh wisatawan yang berkunjung. Berhubung kelinci merupakan ternak alternatif yang mempunyai peluang sebagai penyedia sumber protein hewani yang sehat dan berkualitas tinggi. Namun demikian untuk meningkatkan penyediaan daging kelinci diperlukan perbaikan mutu genetiknya (Sartika, 2000; Lubis, 2017)

Pembinaan lingkungan menciptakan lingkungan yang aman dan bersih khususnya berada pada area yang berdekatan dengan kandang ternak (Sarwono.B, 1985; Manshur ,faiz, 2011). Selain itu perlunya mengembangkan wirausaha salah satunya lewat hasil olahan ternak kelinci (Guntoko et al., 2017).

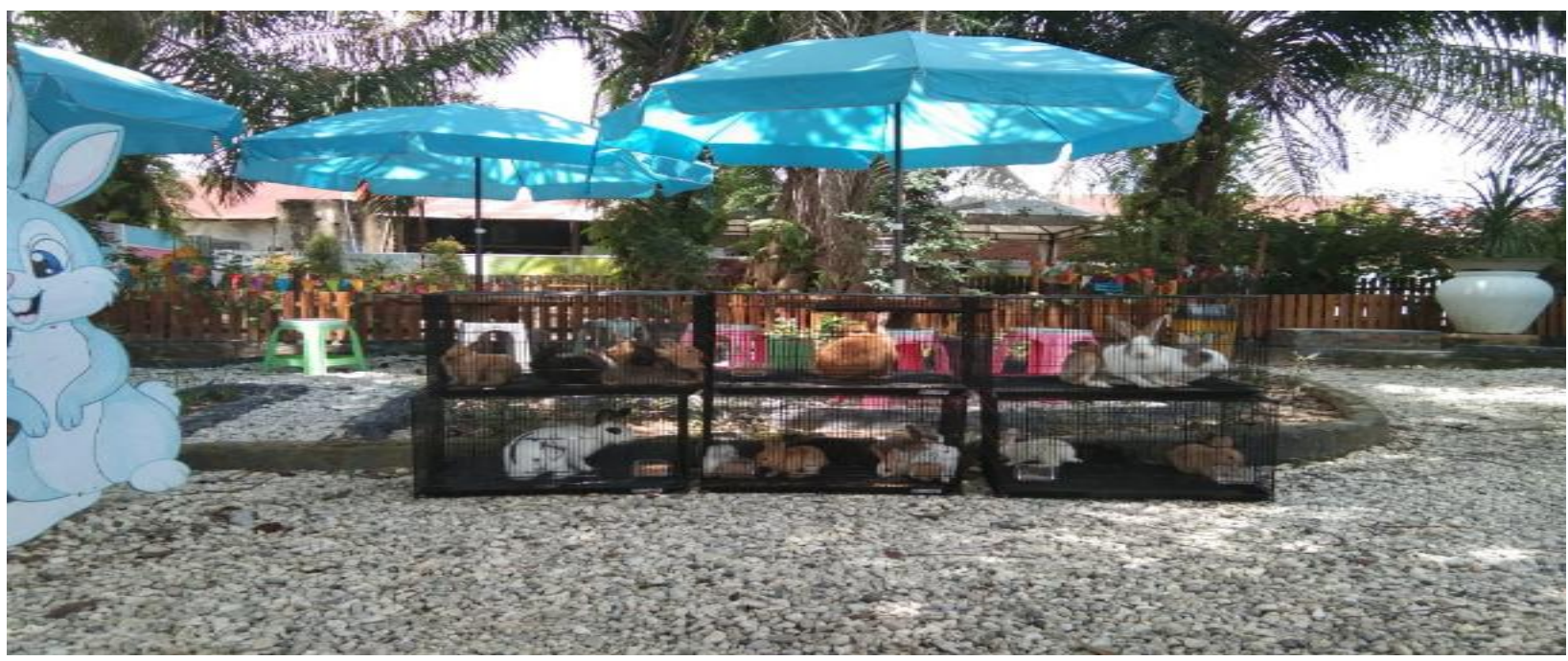

Gambar 2: Kelinci yang ada di Kampoeng Rabbit's

Jika ini dikembangkan lebih lanjut akan menjadi peluang besar bagi pemerintah untuk meningkatkan wisata di dalam kota dan akan menambah pendapatan suatu daerah terutama daerah Tenayan Raya dan para pengunjung akan mengenal daerah ini. Perkembangan kawasan pariwisata tentunya tidak tumbuh begitu saja tanpa ada suatu usaha yang dilakukan, oleh karena itu maka ketersedian sarana dan prasarana sangat dibutuhkan untuk pengembangan sektor ini dan agar dapat menjadi salah satu sektor andalan. Namun, Kualitas lingkungan merupakan bagian integral dari industri wisata. Bagi pengembang dan penyelenggara kagiatan wisata, kualitas lingkungan harus mendapat perhatian utama. Wisata adalah industri yang terkait dengan tujuan wisata dengan karakter-karakter keindahan, keseimbangan, natural, kesehatan, dan kualitas lingkungan yang terjamin. Saat ini, kata "lingkungan" sering muncul sebagai salah satu kunci sukses penyelenggara wisata.

Di daerah Kelurahan Mentangor tepatnya di Kecamatan Tenayan Raya beberapa masyarakatnya yang bekerja sebagai pedagang, pegawai negeri sipil, dan juga pegawai swasta, di sana juga terdapat 


\section{Rangkiang: لlurnal Pengabdian Pada Masyarakat UP3M STKIP PER/ Sumatera Barat}

Vol. 1 (Juni 2019): 1 - 12

pasar sehingga diharapkan bisa meningkatkan jumlah kunjungan pada pariwisata tersebut. Sebagai tempat pariwasata yang ingin dikembangkan ada beberapa hal yang di pertimbangkan seperti pendanaan, dan sumber daya yang menunjang tempat pariwisata tersebut. Karena masih menuju proses perkembangan untuk menjadi pariwisata yang dikenal seluruh kalangan, tempat wisata tersebut sekarang masih didanai oleh pemilik tempat pariwisata tersebut. Untuk sumber daya alam yaitu berbagai macam kelinci nya itu sendiri dan lingkungan yang asri menjadikan tempat tersebut cocok untuk di jadikan tempat pariwisata pemerintah provinsi. Tapi permasalahannya akses untuk ketempat tersebut lumayan sulit karena jalan yang masih belum diaspal.

Pemberdayaan Kampoeng Rabbit's ini tentu akan mewujudkan daerah Tenayan Raya menjadi objek wisata yang akan di perhitungkan bagi Pemprov Riau sebagai objek wisata utama dikota Pekanbaru. Yang akan memberikan sumbangan pendapatan bagi Pekanbaru karena semakin banyak pengunjung yang ke kota Pekanbaru akan membuat pendapatan semakin banyak berdatangan dan membuat kota Pekanbaru menjadi lebih di kenali oleh masyarakat terutama daerah Tenayan Raya dimana tempat wisata itu berdiri. Tempat wisata Kampoeng Rabbit's ini awalnya hanya sebagai tempat koleksi kelinci dan berawal dari hobi tersebut maka dikembangkanlah tempat itu dan dijadikan tempat wisata edukasi yang ramah akan keluarga di lokasi itu terdapat banyak pohon pohon sawit sebab tempat wisata ini memang terletak di daerah yang memiliki banyak pepohonan sawit.

Berdasarkan penjelasan yang terdapat pada latar belakang dapat dirumuskan beberapa permasalahan yaitu terkait dengan cara pengelolaan Kampoeng Rabbit's menjadi tempat wisata yang ramah keluarga dan perencanaan dalam mengembangkan Kampoeng Rabbit's agar menjadi tempat pariwisata yang memiliki prospek kedepannya. Tujuan yang hendak dicapai dalam program bina desa ini adalah Merancang pengelolaan Kampoeng Rabbit's menjadi tempat wisata yang ramah keluarga dan membangun perencanaan dalam mengembangkan Kampoeng Rabbit's agar menjadi tempat pariwisata yang memiliki prospek kedepannya.

Kelinci adalah hewan jenis purba pada mulanya kelinci digolongkan sebagai hewan jenis "Rodentia" karena sering mengerat. Tahun 1912 katagori Rodentia digugurkan karena kelinci memiliki perbedaan tertentu dalam giginya. Istilah yang tepat "Logomorpha' dan spesifikasinya masuk katagoriLagormopha Leporidae sebagaimana hewan jenis Hare. Kelinci merupakan golongan ternak herbivora yang mempunyai sifat coprophage/cecotrophy Sifat ini merupakan ciri khas dari kelinci, yaitu tingkah laku kelinci memakan kembali kotoran (faeces) lunak langsung dari anusnya (coprophage pellets) yang terjadi pada malam hari, sehingga disebut juga Ruminansia semu (pseudo-ruminant). Walaupun memiliki caecum (bagian pertama usus besar) yang besar, kemampuan kelinci dalam mencerna serat kasar terbatas, tidak sebanyak ruminansia. Dalam peternakan kelinci, kelangsungan hidupnya akan sangat tergantung perhatian dan tatalaksana pemeliharaan dari peternaknya. Jenis, jumlah, dan mutu pakan yang diberikan sangat menentukan pertumbuhan, perkembangan, kesehatan, dan produksi. (Brahmantiyo \& Raharjo, 2005; Muslih.dkk, 2010)

Dari catatan sejarah, kelinci pertama kali dibawa ke tanah Jawa oleh orang-orang dari Belanda pada tahun 1835. Waktu itu, kelinci sudah jadi ternak hias. Kelinci lokal dari Indonesia yakni jenis kelinci jawa (Lepus negricollis) dan kelici sumatera (Nesolagus netseherischlgel). Kelinci jawa, diperkirakan masih ada di hutan-hutan sekitar wilayah Jawa Barat. Warna bulunya cokelat perunggu kehitaman. Ekornya berwarna jingga dengan ujungnya yang hitam. Berat kelinci jawa dewasa bisa mencapai $4 \mathrm{~kg}$. Sedangkan kelinci Sumatera, merupakan satu-satunya kelinci asli Indonesia. Habitatnya adalah hutan di pegunungan Pulau Sumatera. Panjang badannya mencapai $40 \mathrm{~cm}$. Warna bulunya kelabu cokelat kekuningan. Kelinci yang berkembang di Indonesia merupakan hasil penyebarluasan program pemerintah yang bertujuan untuk mencukupi kebutuhan protein hewani. Kini, perkembangannya sangat beragam sesuai dengan tujuan produksinya, yaitu dikembangkan sebagai ternak laboratorium, 


\section{Rangkiang: لlurnal Pengabdian Pada Masyarakat UP3M STKIP PER/ Sumatera Barat}

Vol. 1 (Juni 2019): 1 - 12

ternak kesayangan, ternak penghasil kulit dan ternak penghasil daging (Brahmantiyo \& Raharjo, 2005; Istiana \& Zakariya, 2013)

Secara konseptual pemeberdayaan (emperworment) berasal dari kata power (kekuasaan atau keberdayaan). Pemberdayaan menunjuk pada kemampuan orang. Khususnya kelompok rentan dan lemah sehingga berpartisipasi dalam proses pembangunan dan keputusan-keputusan yang mempengaruhi mereka (Bariroh, Wafiatiningsih, dkk, 2010). Pemberdayaan ini merupakan acuan bagi pengelola kelinci di Kampoeng Rabbit's ini untuk terus dapat mengembangkan tempat wisata ini.Pengelola Kampoeng Rabbit's juga berorientasi kepada kepuasan pelanggan. Kepuasan pelanggan merupakan salah satu faktor penentu keberhasilan sebuah usaha. Selain itu kepuasan pelanggan dapat menjadi alat bersaing bagi suatu pengelola usaha dalam menghadapi para pesaingnya (Narisah, Bambang, \& Budi, 2012).

Usaha untuk mewujudkan kepuasan pelanggan ini secara terus dilakukan oleh pengelola Kampoeng Rabbit's. Namun disisi lain, masih terdapatnya berbagai kendala dari objek wisata ini diantaranya kurangnya promosi kepada masyarakat di sekitar seperti minimnya spanduk atau baliho dan promosi melalui media sosial maupun media cetak sebagai usaha pengenalan lokasi Kampoeng Rabbit's. Kampoeng Rabbit's yang terletak didaerah yang padat penduduk, dan ini mejnjadi potensi penunjang bagi pengembangan wisata ini menjadi objek wisata terkemuka di Kota Pekanbaru.

Kendala ini tentunya akan dapat diatasi dengan adanya kerjasama antar lini di daerah wisata Kampoeng Rabbit's. Perlunya ada koordinasi antara pengelola dengan perangkat desa, masyarakat setempat dan pemerintah daerah untuk mewujudkan Kampoeng Rabbit's menjadi salah satu wahana edukasi ramah keluarga. Hal ini nantinya akan dapat menjadi peluang bisnis bagi mayarakat disekitar objek wisata ini untuk mendorong peningkatan pendapatan masyarakat sekitar tempat wisata ini.

\section{METODE}

Tahapan kegiatan yang dilalui dalam kegiatan program bina desa ini yaitu: Pertama, melakukan survey lokasi yang akan dituju yaitu Kampoeng Rabbit's yang melibatkan semua anggota kegiatan. Tim pelaksana melakukan survey lokasi Kampoeng Rabbit's yang berada di kulim tepatnya jalan kenanga indah, survey melibatkan semua anggota kegiatan. Kegiatan survey ini dilakukan sebanyak 3 (tiga) kali, dimana pada tahapan survey awal ini tim pelaksana secara langsung dapat bertemu dan berkoordinasi dengan perangkat desa dan sekaligus dengan pengelola tempat wisata Kampoeng Rabbit's. Pada tahapan ini kami menggali informasi awal tentang tempat wisata ini, informasi yang tim pelaksana dapat tentunya terkait dengan potensi yang dimiliki oleh Kampoeng Rabbit's maupun kendala yang dihadapi oleh tempat wisata ini. Informasi ini kami jadikan bahan rujukan dasar dalam pelaksanaan kegiatan Program Hibah bina Desa (PHBD) ini.

Kedua, melakukan wawancara terhadap pemilik sekaligus pengelola tempat dan wawancara kepada tokoh masyarakat seperti RT dan RW. Masalah yang dihadapi oleh pemilik wisata ini salah satunya yaitu kurangnya pengetahuan masyarakat Kota Pekanbaru tentang adanya wisata edukasi ini disebabkan sudah menjamurnya tempat wisata yang belanja yang ada di Kota Pekanbaru. Selain itu, hambatan yang dialami oleh pemilik wisata ini terkait dengan akses jalan menuju lokasi yang tidak mudah karena jika para wisatawan melakukan akses jalan ke lokasi. Lokasi wisata ini masih belum memiliki koordinat yang tepat dalam maps dan ini sering kali para wisatawan akan dibawa kejalan yang tidak mudah untuk diakses yaitu jalan setapak dan curam. Pada saat hari hujan maka jalan tersebut akan berlumpur dan berbahaya jika menggunakan kendaraan.

Ketiga, setelah mendapat persetujuan tentu bersama sama dengan tokoh masyarakat dan semua yang terlibat merancang kegiatan pemberdayaan Kampoeng Rabbit's untuk mewujudkan Daerah Tenayan Raya menjadi Objek Wisata ramah keluarga. Keempat, setelah merancang bersama sama maka semua pihak yang terlibat melakukan pengembangan wisata seperti perbaikan akses jalan menuju lokasi 
Vol. 1 (Juni 2019): 1 - 12

ini agar terwujud. Kebutuhan lain yang harus diwujudkan adalah renovasi terhadap tempat wisata Kampoeng Rabbit's, menambah jumlah kelinci yang ada ditempat wisata ini. Menjadikan tempat wisata ini semanarik mungkin, sehingga menjadi pelopor wisata edukasi Kota Pekanbaru. Melakukan Promosi yang optimal agar tempat wisata ini dikenal oleh khalayak ramai.Usaha memperbaiki koordinat lokasi Kampoeng Rabbit's di google maps.

Kelima, Kampoeng Rabbit's ini merupakan daerah wisata yang terletak di Tenayan raya tepatnya di Jalan Kenanga yang tidak jauh dari pasar Tangor. Jika dari pusat kota Pekanbaru berkisar 45 menit menuju akses ke lokasi. Maka lokasi tersebut cocok untuk dijadikan daerah binaan sebab di lihat pada gambaran masyarakat umum di sekitaran daerah tersebut rata rata berporfesi sebagai pedagang dan PNS maka daerah tersebut cocok untuk dijadikan sasaran binaan. Serta Kampoeng Rabbit's tersebut cocok untuk di kembangkan lagi dan di perkenalkan ke khalayak ramai.

Keenam, melakukan promosi ke masyarakat kota Pekanbaru melalui media cetak seperti surat kabar atau melalui media sosial seperti instagram dan facebook. Menambah spanduk atau baliho untuk promosi. Promosi merupakan ujung tombak dari kesuksesan sebuah tempat wisata. Tanpa adanya kegiatan promosi, maka tempat wisata ini tidak akan dikenal dengan baik oleh mayarakat secara luas.

Kemudian dilanjutkan dengan penyusunan program, seperti menyusun rencana program yang akan dijalani. Perumusan dan pengukuran indikator keberhasilan program, seperti merumuskan serta mengukur keberhasilan tentang program yang akan dilaksanakan. Pelaksanaan program, seperti melaksanakan program secara bertahap tahap. Pelaksanaan program yang dilakukan secara terperinci akan memudahkan pelaksana kegiatan ini untuk mencapai target yang telah ditetapkan sebelumnya.

Strategi pembinaan khalayak sasaran, seperti membina sasaran program agar dapat melakukan program tersebut agar berjalan baik. Strategi pembinaan khalayak sasaran dari kegiatan ini yaitu bekerja sama dengan pemilik dan pengelola tempat wisata ini. Selain iu juga menjalin hubungan baik dengan masyarakat sekitar dan melakukan sosialisasi kepada masyarakat. Menggencarkan kegiatan promosi, baik promosi melalui media online (social media) maupun promosi melalui media cetak. Melakukan pelatihan kepada para pengelola tempat terkait bagaimana manjemen startegi yang baik dalam pengelolaan tempat wisata dan juga terkait dengan manajemen servis terhadap konsumen. Perintisan kemitraan, seperti membangun kerjasama dengan sasaran mitra dengan baik. Monitoring dan evaluasi, seperti melakukan evaluasi terhadap kegiatan tersebut. Lokakarya hasil dengan stakeholder, seperti mengenalkan kegiatan ini kepada masyarakt umum. Pelaporan, seperti pelaporan yang terdiri laporan awal, revisi program dan laporan akhir. Dan yang terakhir pemutakhiran data sasaran program per 4 bulan, seperti melakukan evaluasi pasca program terakhir. 
Vol. 1 (Juni 2019): 1 - 12

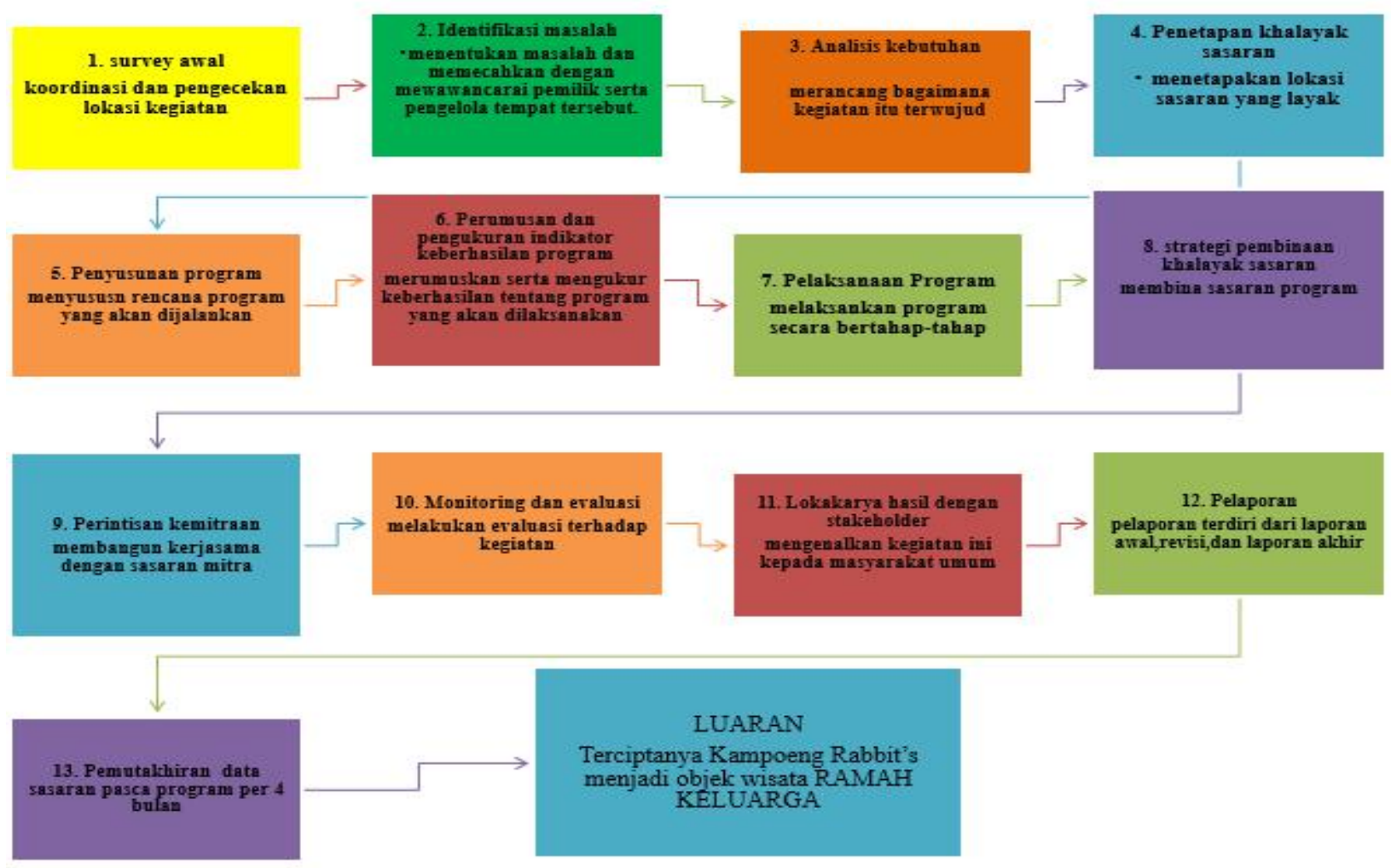

Gambar 3. Tahapan Kegiatan

\section{HASIL DAN PEMBAHASAN}

Dalam pelaksanaan kegiatan pemberdayaan Kampoeng Rabbit's menjadi tempat wisata yang ramah keluarga, dapat kita lihat bahwa Kmapoeng Rabbit's ini memiliki beberapa potensi yang dapat dikembangkan. Adapun beberapa potensi yang dapat dikembangkan dari tempat wisata Kampoeng Rabbit's ini yaitu: 1) Kampoeng Rabbit's ini mempunyai potensi alam yang bagus yang terletak di daerah yang memiliki udara yang sejuk dan asri. 2) Tempat wisata ini merupakan tempat wisata edukasi yang memberikan suasana ramah keluarga yang cocok untuk keluarga besar berwisata. 3) Masyarakat dapat lebih dekat dengan alam dan lebih menyayangi hewan-hewan sekitar seperti kelinci dan tempat wisata ini memberikan edukasi tentang pemahanan cara memelihara kelinci yang benar. 4) Kotoran kelinci ini dijadikan pupuk oleh pemilik sebagai pupuk sawit.

Berdasarkan potensi yang ada, program bina desa pada Kampoeng Rabbit's ini menjalankan tahapan demi tahapan perencanaan dari program yang telah dirancang sebelumnya. Tahapan-tahapan program tersebut kemudian dilaksanakan sesuai dengan tujuan yang akan dicapai. Keseluruhan aspek dari tahapan pelaksanaan ini dilakukan untuk menjadikan Kampoeng Rabbit's menjadi salah satu tempat wisata yang diminati oleh masyarakat yang ada di Kota Pekanbaru maupun masayrakat dari daerah lainnya.

\section{Tabel 1. Tingkat Keberhasilan Pelaksanaan Program}


Vol. 1 (Juni 2019): 1 - 12

Pada tahap sosialisasi Program Hibah Bina Desa ini pada pembinaan Kampoeng Rabbit's dilakukan sosialisasi mengenai pemberdayaan Kampoeng Rabbit's untuk mewujudkan daerah Tenayan Raya menjadi objek wisata edukasi yang ramah Keluarga. Tahap ini mengajak masyarakat sekitar, stakeholder maupun pengunjung yang datang untuk bersama sama meningkatkan pengetahuan tentang adanya objek wisata yang memberikan edukasi tentang kelinci seperti bagaimana cara merawat kelinci dengan baik serta menjadi kawasan objek wisata yang ramah anak.

Tahapan berikutnya yaitu tahap pembangunan, dilakukannya pembuatan kandang kelinci, pembuatan taman baru kelinci, perawatan dan maintenance lokasi, pemasangan photo booth, Pada tahapan promosi kepada masyarakat dilakukan pemasangan spanduk promosi, umbul-umbul, pemasangan atribut denah jalan, sosialisasi secara langsung kepada masyarakat maupun promosi melalui media cetak dengan menyebarkan brosur dan media online (social media) tentang adanya objek wisata edukasi ini dan pemberdayaan Kampoeng Rabbit's. Pada setiap bulannya ketua bersama tim anggota akan melakukan kegiatan monitoring untuk melihat sejauh mana setiap aspek kegiatan yang sudah dirancang dapat direalisasikan serta mengukur tingkat ketercapaian program yang sudah dibuat.

\begin{tabular}{|c|c|c|c|c|c|}
\hline No & Program & Tujuan & & $\begin{array}{l}\text { Indikator } \\
\text { Keberhasilan }\end{array}$ & Tingkat Keberhasilan \\
\hline 1 & $\begin{array}{l}\text { Pemanfaatan media } \\
\text { cetak, media sosial } \\
\text { dan google sebagai } \\
\text { media promosi }\end{array}$ & $\begin{array}{l}\text { Sebagai } \\
\text { promosi } \\
\text { Kampoeng } \\
\text { Rabbit's }\end{array}$ & sarana & $\begin{array}{l}\text { Terbentukya akun } \\
\text { media sosial } \\
\text { Akun media sosial } \\
\text { memiliki } \pm 1.000 \text { orang } \\
\text { pengikut; Kampoeng } \\
\text { wisata mendapatkan } \\
\text { ulasan yang baik dari } \\
\text { google guides }\end{array}$ & $\begin{array}{l}\text { Telah terbentukya akun } \\
\text { media sosial } \\
\text { Akun media sosial saat } \\
\text { ini telah memiliki } \pm \\
1.113 \text { orang pengikut; } \\
\text { Kampoeng wisata } \\
\text { mendapatkan telah } \\
\text { ulasan yang baik dari } \\
\text { google guides dengan } \\
\text { rating } 4,2\end{array}$ \\
\hline
\end{tabular}

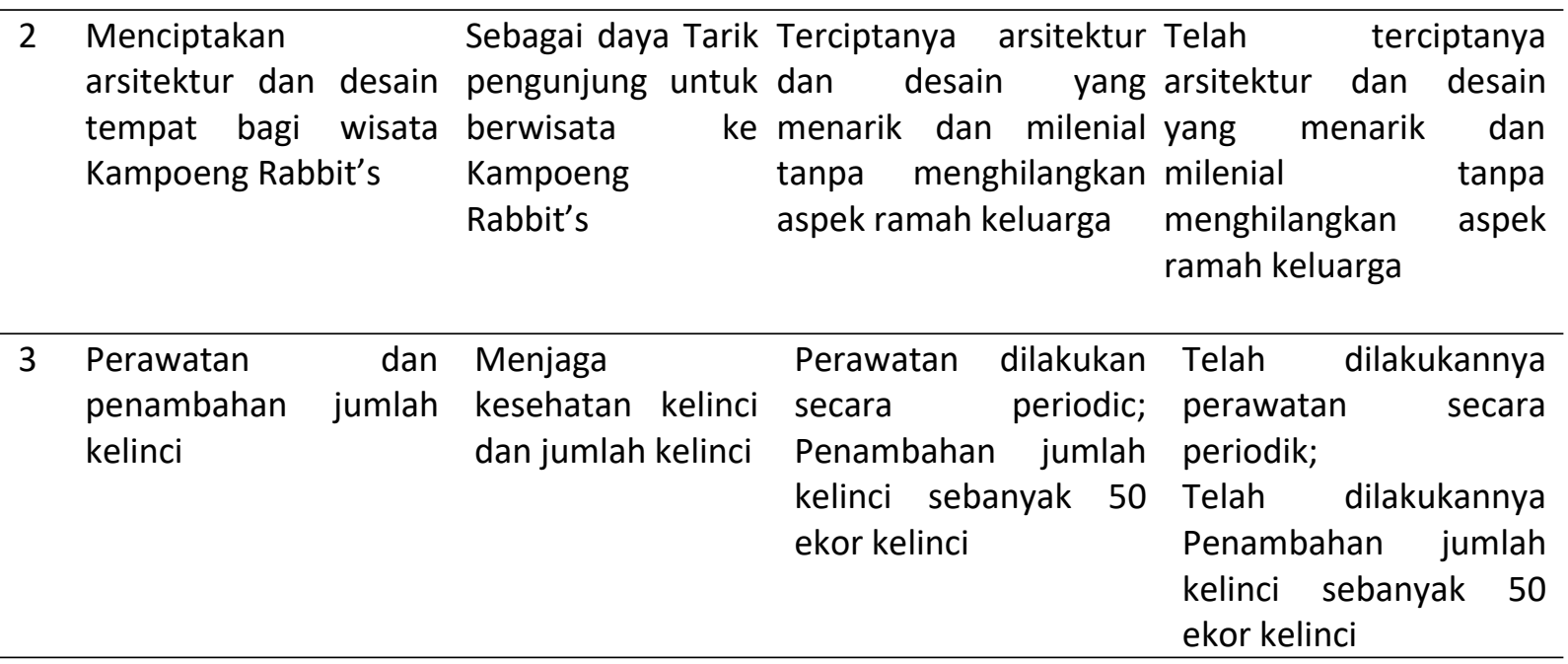


Vol. 1 (Juni 2019): 1 - 12

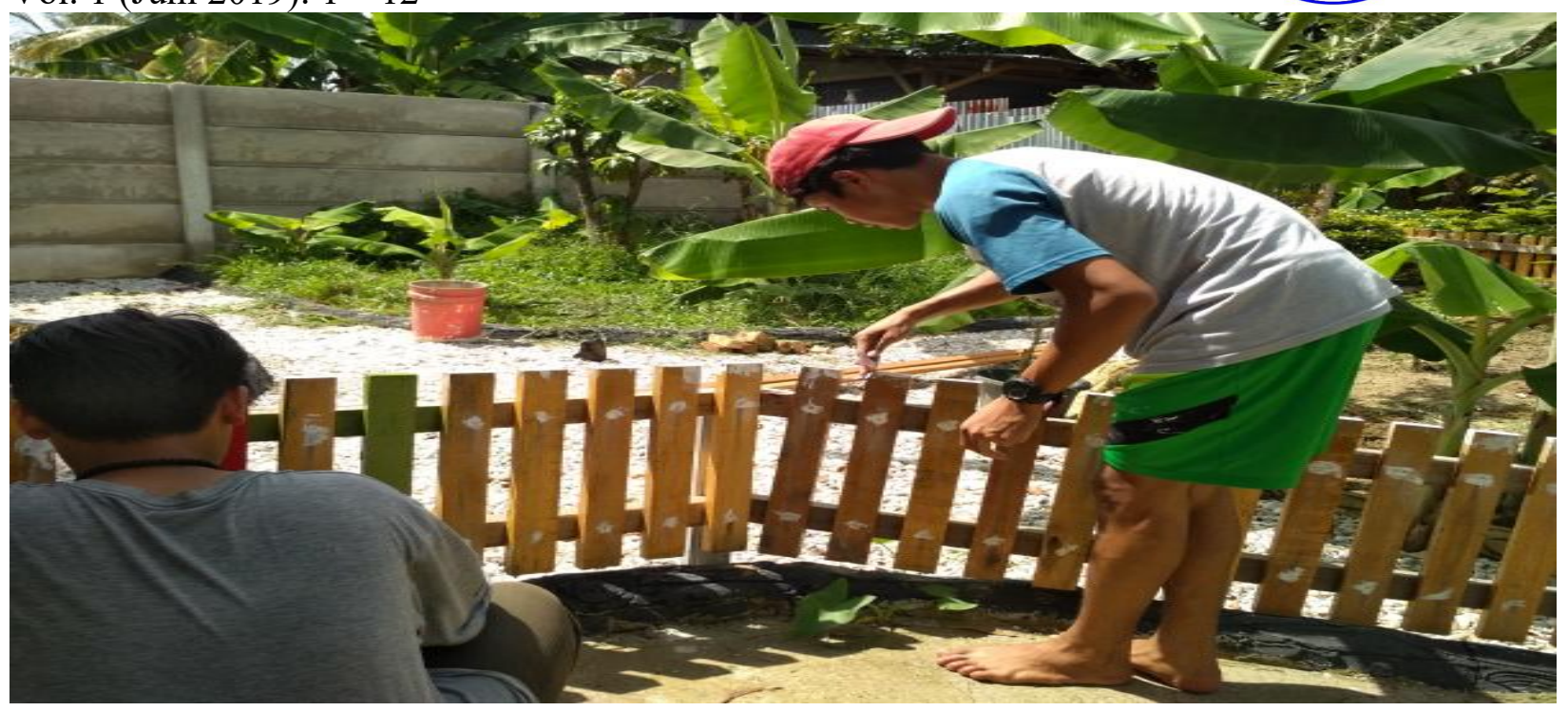

Gambar 4. Pembuatan Taman Kelinci

Selanjutnya dilakukan kegiatan lokakarya, kegiatan lokakarya dilaksanakan dengan menghadirkan Kepala Lurah, Ketua RT dan Ketua RW dalam tahap mengenalkan

kegiatan yang telah dilakukan kepada masyarakat umum serta mensosialisaikan keberlanjutan program yang akan dilaksanakan agar dapat tercapai dengan baik.

Tabel 2. Perintisan Kemitraan

\begin{tabular}{ccc}
\hline No & Pihak Yang Terlibat & Peran Pihak Yang Terlibat \\
\hline 1 & Tim pengusul & Menerapkan keilmuan yang dipelajari di Perguruan Tinggi \\
& & terkait manajemen strategi pengelolaan tempat wisata, \\
& perawatan kelinci, maintenance tempat dan lokasi \\
& Kampoeng Rabit's dan promosi ke masyarakat Kota \\
& Pekanbaru melalui media cetak ataupun media sosial.
\end{tabular}

$2 \quad$ Perangkat Desa

Mengajak masyarakat untuk ikut andil dalam kegiatan ini seperti salah satunya memfasilitasi dan mendukung berkembangnya tempat wisata Kampoeng Rabbit's dan mengajak masyarakat untuk mempromosikan tempat wisata tersebut dan menumbuhkan rasa memiliki tempat wisata Kampoeng Rabit's bagi setiap masyarakat

\begin{tabular}{lll}
\hline Pengelola tempat wisata & Membangun tempat wisata yang ramah keluarga dan \\
Kampoeng Rabbit's & menarik minat wisatawan. Mengelola tempat wisata, \\
& & mengajak masyarakat untuk dapat berkunjung ke \\
& Kampoeng Rabbit's.
\end{tabular}

Keberlanjutan pasca pelaksanaan program PHBD ini maka diperlukannya strategi pembinaan khalayak sasaran dan Perintisan kemitraan, agar kegiatan pemberdayaan Kampoeng Rabbit's sebagai wisata edukasi ramah keluarga yang sudah dilaksanakan dapat terus berkekelanjutan dan berkembang dengan baik. Strategi pembinaan khalayak sasaran dari kegiatan ini yaitu bekerja sama dengan pemilik dan pengelola tempat wisata ini. Selain iu juga menjalin hubungan baik dengan masyarakat sekitar dan 


\section{Rangkiang: لlurnal Pengabdian Pada Masyarakat UPSM STKIP PGRl Sumatera Barat}

Vol. 1 (Juni 2019): 1 - 12

melakukan sosialisasi kepada masyarakat. Menggencarkan kegiatan promosi, baik promosi melalui media online (sosial media) maupun promosi melalui media cetak. Melakukan pelatihan kepada para pengelola tempat terkait bagaimana manjemen startegi yang baik dalam pengelolaan tempat wisata dan juga terkait dengan manajemen servis terhadap konsumen. Perintisan kemitraan disini yaitu membangun kerja sama dengan pemilik tempat wisata tersebut sehingga program yang telah terlaksana dapat terus berlanjut (Dalimunthe, 2019).

Berdasarkan kondisi wisata Kampoeng Rabbit's setelah adanya kegiatan pemberdayaan ini, maka dapat diihat bahwa potensi keberlanjutan dari program ini cukup besar. Bisa kita lihat dari kondisi awal masyarakat sasaran sebagian tidak mengetahui akan adanya Kampoeng Rabbit's ini karena kurangnya promosi serta pengetahuan tentang adaanya wisata edukasi ini. Namun pada saat tim PHBD membuat beberapa spanduk, umbul umbul, denah jalan, melalui brosur, media online, mendapatkan respon positif dari warga sekitar akan adanya kegiatan ini. Kegiatan promosi ini kedepannya diharapkan dapat menjadikan Kampoeng Rabbit's lebih dikenali lagi oleh masyarakat luas. Potensi lainnya yaitu dengan adanya lingkungan hijau dan asri serta udara yang sejuk, menjadikan Kampoeng Rabbit's sebagai peluang tempat wisata alam yang menjajikan kedepannya. Tempat wisata ini merupakan tempat wisata edukasi yang memberikan suasana ramah keluarga yang cocok untuk keluarga besar berwisata.

Selain itu, Kampoeng Rabbit's juga dapat menjadi tempat wisata kuliner dengan menu khas "sate kelinci" akan menjadi daya tarik bagi para pengunjung. Peningkatan jumlah pengunjung ke tempat wisata ini akan menjadi peluang usaha juga bagi masyarakat di sekitar tempat wisata Kampoeng Rabbit's untuk meningkatkan pendapatan mereka. Tahap selanjutnya mengadakan lokakarya dengan menghadirkan Kepala Lurah, Ketua RT dan Ketua RW dalam tahap mengenalkan kegiatan yang telah dilakukan kepada masyarakat umum serta mensosialisaikan keberlanjutan program yang akan dilaksanakan agar dapat tercapai dengan baik.

\section{SIMPULAN}

Berdasarkan kegiatan pemberdayaan Kampoeng Rabbit's untuk mewujudkan daerah Tenayan Raya menjadi objek wisata ramah keluarga maka dapat ditarik beberapa kesimpulan sementara diantanya: 1) Kampoeng Rabbit's sangat cocok untuk tempat wisata keluarga terlebih lagi dengan anak anak karena tempat wisata ini memberikan edukasi tentang pemahanan cara memelihara kelinci dengan benar Masyarakat. 2) Daerah Tenayan Raya terutama di Jalan Kenanga Kelurahan Mentangor Kec. Tenayan Raya dapat merasakan secara langsung dampak adanya wisata Kampoeng Rabbit's ini. 3) Dengan adanya kegiatan ini dapat meningkatkan pendapatan pengelola Kampoeng Rabbit's. 4) Menjadikan objek wisata Kampoeng Rabbit's dapat dikenal dan diketahui oleh banyak orang terutama luar daerah Pekanbaru. 5) Dengan adanya kerja sama dari pemilik objek wisata dan tokoh masyarakat setempat seperti Ketua RT dan Ketua RW dapat mengembangkan program pemberdayaan Kampoeng Rabbit's untuk mewujudkan daerah Tenayan Raya menjadi objek wisata yang Ramah keluarga.

Dalam upaya mewujudkan pemberdayaan Kampoeng Rabbit's untuk lebih baik lagi kedepannya, maka dalam kegiatan ini terdapat beberapa saran dan tindak lanjut sementara yang dapat diusulkan: 1) Masih belum optimalnya keadaan infrastruktur (jalan) menuju ke lokasi wisata ini, diharapkan pemerintah Kota Pekanbaru dapat mengupayakan untuk segera merencanakan pembangunan jalan ke wilayah ini. 2) Koordinat lokasi wisata ini belum terditeksi oleh koordinat maps yang tepat, maka diharapkan dengan adanya umbul-umbul dan denah jalan dapat memberikan petunjuk jalan yang benar menuju lokasi bagi para pengunjung. 3) Kurangnya promosi kepada masyarakat, maka diharapkan dapat terus melakukan promosi melalui media sosial maupun media cetak sebagai usaha pengenalan lokasi Kampoeng Rabbit's. 4) Diharapkan adanya kerjasama antar lini yaitu koordinasi antara pengelola 
Vol. 1 (Juni 2019): 1 - 12

dengan perangkat desa, masyarakat setempat dan pemerintah daerah untuk mewujudkan Kampoeng

Rabbit's menjadi salah satu wahana edukasi ramah keluarga.

\section{UCAPAN TERIMAKASIH}

Terima kasih kami sampaikan kepada Kementrian Riset Teknologi dan Pendidikan Tinggi atas dana yang telah diberikan untuk kegiatan Program Hibah Bina Desa sebagai salah satu wujud pengabdian kepada masyarakat dan juga kepada Universitas Muhammadiyah Riau (UMRI) yang telah memberikan dukungan kepada dalam menyelenggarakan kegiatan Program Hibah Bina Desa ini.

\section{DAFTAR PUSTAKA}

Bariroh, N. R., Wafiatiningsih, Sulistyono, I., A., \& Saptati, R. a. (2010). Prospek Pengembangan Kelinci Non-Lokal Di Kalimatan Timur. Lokakarya Nasional Potensi Dan Peluang Pengembangan Usaha Agribisnis Kelinci, 131-138.

Brahmantiyo, B., \& Raharjo, Y. C. (2005). Pengembangan Pembibitan Kelinci di Pedesaan dalam Menunjang Potensi dan Prospek Agrisbisnis Kelinci. Lokakarya Nasional Potensi Dan Peluang Pengembangan Usaha Agribisnis Kelinci, 75-86.

Dalimunthe, N. W. Y. (2019). Pembentukan dan Pembinaan Kelompok Tani Kelinci dalam Rangka Pengembangan Desa Wisata di Soropati, Hargotirto, Kokap, Kulon Progo. Jurnal Pengabdian Dan Pengembangan Masyarakat, 2(1), 189. https://doi.org/10.22146/jp2m.48334

Guntoko, N. A. S., Azizah, S., \& Kusumastuti, A. E. (2017). Model Pemberdayaan Kelompok Ternak Kelinci melalui Program Pelatihan Pertanian dan Perdesaan Swadaya (studi kasus Kelompok Ternak Kelinci "Mandiri Jaya" di Desa Ngijo, Kecamatan Karangploso, Kabupaten Malang). Jurnal IImuIImu Peternakan, 27(3), 1-6. https://doi.org/10.21776/ub.jiip.2017.027.03.01

Istiana, S., \& Zakariya, A. Z. (2013). Potensi Pengembangan Ternak Kelinci Mendukung Peningkatan Gizi Masyarakat di Kota Batu. Seminar Nasional : Menggagas Kebangkitan Komoditas Unggulan Lokal Pertanian Dan Kelautan, 229-235.

Lubis, A. P. (2017). Penentuan Jenis Kelinci Pedaging Terbaik Dengan Menggunakan Metode Fuzzy Muti Criteria Decision Making. JURTEKSI, 4(1), 57-64. https://doi.org/10.33330/jurteksi.v4i1.24

Manshur, faiz. 2011. Kelincil.. Nuansa; bandung

Muslih dkk.2010. Tatalaksana pemberian pakan untuk menunjang agrobisnis kelinci . Balai penelitian ternak : Bogor

Narisah, Bambang, A. N., \& Budi, H. (2012). Pengaruh Bauran Pemasaran Terhadap Tingkat Kepuasan Pelanggan Warung Sate Kelinci Di Kota Batu. Geography, 4(2), 1-12.

Sartika, T. (2000). Strategi pemuliaan sebagai alternatif peningkatan produktivitas kelinci pedaging. Lokakarya Nasional Potensi Dan Peluang Pengembangan Usaha Agribisnis Kelinci, 93-98.

Sarwono. B, 1985, Beternak Kelinci Unggul, Penebar Swadaya, Jakarta. 
Rangkiang: Lurna/ Pengabdian Pada Masyarakat UPSM STKIP PER/ Sumatera Barat

Vol. 1 (Juni 2019): 1 - 12 